\title{
Meat Safety from Farm to Slaughter-Risk-Based Control of Yersinia enterocolitica and Toxoplasma gondii
}

\author{
Nevijo Zdolec (1) and Marta Kiš * \\ Department of Hygiene, Technology and Food Safety, Faculty of Veterinary Medicine, University of Zagreb, \\ Heinzelova 55, 10000 Zagreb, Croatia; nzdolec@vef.hr \\ * Correspondence: mkis@vef.hr; Tel.: +38-51-239-0199
}

check for updates

Citation: Zdolec, N.; Kiš, M. Meat Safety from Farm to SlaughterRisk-Based Control of Yersinia enterocolitica and Toxoplasma gondii. Processes 2021, 9, 815. https:// doi.org/10.3390/pr9050815

Academic Editor: José Manuel Moreno-Rojas

Received: 13 April 2021

Accepted: 5 May 2021

Published: 7 May 2021

Publisher's Note: MDPI stays neutral with regard to jurisdictional claims in published maps and institutional affiliations.

Copyright: (c) 2021 by the authors. Licensee MDPI, Basel, Switzerland. This article is an open access article distributed under the terms and conditions of the Creative Commons Attribution (CC BY) license (https:/ / creativecommons.org/licenses/by/ $4.0 /)$.

\begin{abstract}
The implementation of the traditional meat safety control system has significantly contributed to increasing food safety and public health protection. However, several biological hazards have emerged in meat production, requiring a comprehensive approach to their control, as traditional methods of meat inspection at the slaughterhouse are not able to detect them. While national control programs exist for the most important meat-related hazards, similar data are still lacking for certain neglected threats, such as Yersinia enterocolitica or Toxoplasma gondii. The obstacle in controlling these hazards in the meat chain is their presence in latently infected, asymptomatic animals. Their effective control can only be achieved through systematic preventive measures, surveillance or monitoring, and antimicrobial interventions on farms and in slaughterhouses. To establish such a system, it is important to collect all relevant data on hazard-related epidemiological indicators from the meat chain, which should provide relevant guidance for interventions at the harvest and post-harvest stage. The proposed approach is expected to improve the existing system and provide many opportunities to improve food safety and public health.
\end{abstract}

Keywords: meat safety; biological hazards; Yersinia enterocolitica; Toxoplasma gondii; food chain information

\section{Introduction}

Different husbandry systems of farm animals are burdened with specific biological and chemical hazards, which are transmitted throughout the meat production chain from the farm to the consumer [1]. In the past, appropriate preventive measures and control systems were developed on the basis of systematic hazard analyzes and designed according to epidemiological conditions at specific times. For example, at the beginning of veterinary controls on farm animal health and meat safety (19th century), controls were already risk-based and focused on zoonoses such as tuberculosis, cysticercosis, or trichinosis [2]. Nowadays, due to systematic controls and the implementation of veterinary and hygiene measures, these zoonoses occur less frequently and the risk is negligible [3]. However, this is not equally true for all parts of the world [4-7].

Recently, "new" biological hazards have emerged in livestock and meat production, requiring a comprehensive approach to their control and monitoring. These hazards existed before, but prevention and control measures did not comprehensively address them [8,9]. Specifically, the safety of meat is mainly threatened by the so-called invisible hazards, i.e., biological and chemical contaminants such as bacteria, viruses, parasites, toxins, residues of veterinary drugs, environmental contaminants, etc., which do not cause clinical symptoms or visible changes in the meat or animal organs [1]. Traditional methods of meat inspection in slaughterhouses are not able to detect these hazards, which requires a more risk-based approach to reduce the risk to public health $[8,9]$. Therefore, the main biological hazards in meat production, both at farm and slaughterhouse level, are Salmonella spp., Campylobacter spp., Yersinia enterocolitica, verotoxic Escherichia coli, bacteria with ESBL/AmpC gene, Trichinella, and Toxoplasma gondii [10]. The obstacle in controlling these hazards in the meat chain is their presence in latently infected, asymptomatic animals. As detection of these 
hazards on each individual carcass is impractical and unprofitable, their effective control is only possible through the application of a system of prevention and control measures on farms and in slaughterhouses [11,12].

In recent years, efforts have been made to establish a comprehensive integrated riskbased meat safety assurance system $[9,13]$. It is based on the identification of current public health risks and the implementation of control measures throughout the agri-food chain. In practice, this means that control and intervention measures are designed in slaughterhouses (harvest stage) according to previously identified hazards/risks on the farm (pre-harvest stage). The categorization of farms and slaughterhouses should help to better inform consumers about the level of safety on farms, which in turn may affect the practice of high-risk farms or slaughterhouses [9]. The categorization of farms and slaughter animals is based on food chain information (FCI) collected and recorded from the farm management system, surveillance, or monitoring programs and results of official controls [14,15]. These data guide the official veterinarian/risk manager in slaughterhouses when deciding on ante-mortem inspections, logistic slaughter, slaughter bans, visual or traditional meat inspection methods, decontamination procedures, and sampling for laboratory analysis. In the case of non-compliant data from the production chain on these hazards, risk reduction or elimination measures are chosen, such as decontamination of carcasses, freezing of meat, detailed post-mortem inspection, or additional laboratory testing $[10,13]$. Since the risk of bacterial pathogens in meat depends largely on the hygiene of the process between slaughterhouses [11], it is necessary to carry out risk categorization. In this way, improved meat safety is achieved in relation to the technology used in the slaughter process (Good Hygiene Practice, Good Manufacturing Practice) and, if necessary, the possibilities of decontamination technologies [11].

With regard to the listed priority biological hazards (pathogenic bacteria and parasites), the categorization of animals/farms should take into account the results of previous laboratory tests (if available) and adjust sampling and analysis plans according to trends $[9,13]$. Reliable data on certain prioritized threats, such as Yersinia enterocolitica or Toxoplasma gondii are still lacking at the farm/slaughterhouse level. The FCI needs to be complemented by Harmonized Epidemiological Indicators (HEIs), which provides the risk score of a specific part of the meat chain [14,15]. The purpose of this paper is to present the elements of a risk-based control system from farm to slaughterhouse, with a particular focus on Y. enterocolitica and T. gondii as examples of underestimated meat-borne hazards within the existing regulatory framework.

\section{Biological Hazards in the Meat Chain}

Bacterial intestinal pathogens have always been a challenge in meat hygiene, such as Salmonella spp., Yersinia spp., Campylobacter spp., Listeria monocytogenes, or Escherichia coli [1]. They are not physiologically present in the meat but get there during the slaughter processing of the animals, but also in the further course of handling and processing of meat by equipment, surfaces, and personnel $[11,12]$. Therefore, their finding on the meat (surface contamination) is due to their presence in slaughtered animals [1]. Recent systematic studies show that the prevalence of Salmonella and Campylobacter in broilers or pigs is over $20 \%$ and $50 \%$, respectively, but it depends on the type of samples (from animals or the environment-the farm), the rearing method, and the area of observation (Table 1). The seroprevalence of $Y$. enterocolitica is highest in pigs and poses a greater meat safety challenge than Salmonella in some countries [15]. Shiga toxin-producing E. coli (STEC) has also shown an upward trend among foodborne zoonoses in recent years, but there are few data on its prevalence on farms. Regarding the results of national programs for the surveillance of specific pathogens of meat-borne diseases, such as in the EU, there are significantly lower prevalence compared to global/continental scientific studies (Table 2). The number of EU countries reporting the results of their on-farm bacterial surveillance programs is inconsistent and varies considerably across species. This is particularly true at the slaughter stage, where data are most complete only for Salmonella in pigs, and there 
are almost no data for the prevalence of Yersinia and STEC on carcasses of slaughtered animals (Table 3). Of the parasitic zoonoses, Toxoplasma gondii is considered a priority hazard in the meat production chain. This is supported by data on its high prevalence in pigs worldwide [16] and in ruminants and certain wildlife species [17]. National control programs exists for several prioritized meat-related hazards in many countries, but similar programs for Y. enterocolitica and T. gondii are missing [15].

Table 1. Recent studies on (sero)prevalence of main biological hazards in farm animals.

\begin{tabular}{|c|c|c|c|c|}
\hline Animal Species & Biological Hazard & Sampling & Prevalence & Country, Reference \\
\hline \multirow{2}{*}{ Broilers } & Salmonella spp. & \multirow{2}{*}{$\begin{array}{c}\text { Environmental } \\
\text { samples-boot sock, } \\
\text { feces, litter, drag swab, } \\
\text { feed, water, grass, soil, } \\
\text { compost }\end{array}$} & $\begin{array}{c}22.9 \% \text { (95\% CI: } \\
14.5-34.2 \% \text { ) and } 19.9 \% \\
(95 \% \text { CI: } 7.1-44.8 \%) \text { for } \\
\text { conventional and } \\
\text { alternative samples, } \\
\text { respectively }\end{array}$ & \multirow{2}{*}{$\begin{array}{l}\text { USA (systematic } \\
\text { review), [18] }\end{array}$} \\
\hline & Campylobacter spp. & & $\begin{array}{c}\text { 15.8\% (95\% CI: 3-52\%) } \\
\text { and } 52.8 \%(95 \% \mathrm{CI}: \\
32.8-71.8 \%) \text { for } \\
\text { conventional and } \\
\text { alternative samples, } \\
\text { respectively }\end{array}$ & \\
\hline \multirow{2}{*}{$\begin{array}{l}\text { Pigs, poultry, cattle, } \\
\text { goat, sheep }\end{array}$} & Salmonella spp. & \multirow{2}{*}{ Gut samples } & $\begin{array}{c}27.8 \%(95 \% \text { CI } 20.4-36.7) \\
40.2 \%(95 \% \text { CI } 32.7-48.2) \\
15.4 \% \text { (95\% CI } 11.7-20.0) \\
16.8 \% \text { (95\% CI } 11.4-24.6) \\
13.6 \% \text { (95\% CI } 8.5-21.1)\end{array}$ & \multirow{2}{*}{$\begin{array}{l}\text { Africa (systematic } \\
\text { review), [19] }\end{array}$} \\
\hline & Campylobacter spp. & & $\begin{array}{c}15.4 \% \text { (95\% CI } 8.4-26.6) \\
13.4 \% \text { (95\% CI } 9.8-18.0) \\
4.5 \% \text { (95\% CI } 2.9-6.9) \\
2.2 \%(95 \% \text { CI } 1.1-4.3) \\
4.5 \%(95 \% \text { CI } 2.8-7.2)\end{array}$ & \\
\hline Cattle & Salmonella spp. & Feces & $9 \%(95 \%$ CI 7-11\%) & $\begin{array}{c}\text { Global (systematic } \\
\text { review), [20] }\end{array}$ \\
\hline \multirow[t]{2}{*}{ Pigs } & Yersinia enterocolitica & \multirow{2}{*}{$\begin{array}{l}2353 \text { meat juice } \\
\text { samples, } 259 \text { farms }\end{array}$} & $\begin{array}{l}57 \% \text { of pigs and } 85 \% \\
\text { of farms }\end{array}$ & \multirow[t]{2}{*}{ [15] } \\
\hline & Toxoplasma gondii & & $3 \%$ of pigs, $9 \%$ of farms & \\
\hline \multirow{3}{*}{ Pigs } & Yersinia enterocolitica & \multirow{3}{*}{$\begin{array}{l}57 \text { indoor fattening pig } \\
\text { farms, serum }\end{array}$} & $72.3 \%$ & \multirow{3}{*}{ [15] } \\
\hline & Toxoplasma gondii & & $<1 \%$ & \\
\hline & Salmonella spp. & & $1.9-17.6 \%$ & \\
\hline Pigs & Toxoplasma gondii & $\begin{array}{c}148,092 \text { pigs from } 47 \\
\text { countries }\end{array}$ & 19\% (95\% CI: 17-22\%) & $\begin{array}{c}\text { Global (systematic } \\
\text { review), [16] }\end{array}$ \\
\hline $\begin{array}{l}\text { Pigs, sheep, cattle, wild } \\
\text { boars, moose }\end{array}$ & Toxoplasma gondii & & $\begin{array}{c}6 \% \text { in domestic pigs } \\
\text { (CI 95\%: } 3-10 \%), 23 \% \text { in } \\
\text { sheep (CI 95\%: 12-36\%), } \\
7 \% \text { in cattle (CI } 95 \%: \\
1-21 \%), 33 \% \text { in wild } \\
\text { boars (CI 95\%: } 26-41 \%), \\
\text { and } 16 \% \text { in moose } \\
\text { (CI } 95 \%: 10-23 \%)\end{array}$ & $\begin{array}{c}\text { Nordic-Baltic region in } \\
\text { northern Europe } \\
\text { (systematic review), } \\
{[17]}\end{array}$ \\
\hline
\end{tabular}


Table 2. Official data on (sero)prevalence of main biological hazards in farm animal [21].

\begin{tabular}{|c|c|c|c|c|}
\hline Biological Hazard & Animal Species & Sampling & Prevalence & $\begin{array}{c}\text { Countries Reported } \\
\text { the Data }\end{array}$ \\
\hline \multirow{3}{*}{ Salmonella spp. } & Broilers & $\begin{array}{c}\text { National Control } \\
\text { Programs, } \mathrm{n}=361,974 \\
\text { flocks }\end{array}$ & $\begin{array}{c}3.48 \% \text {, range by } \\
\text { countries: } 0-18.4 \%\end{array}$ & 29 EU countries \\
\hline & Cattle & $\begin{array}{l}\text { Feces, farm } \\
\text { environmental samples; } \\
25,687 \text { cattle, } 3962 \text { herds }\end{array}$ & $\begin{array}{c}4.13 \% \text { of animals and } \\
0.88 \% \text { of herds }\end{array}$ & 13 EU countries \\
\hline & Pigs & $\begin{array}{c}\text { Caecum, feces, lymph } \\
\text { nodes; } 16,947 \text { animals, } \\
\text { 71,006 slaughter animal } \\
\text { batch, } 732 \text { herds }\end{array}$ & $\begin{array}{l}0.97 \% \text { in pigs, } 53.2 \% \text { in } \\
\text { slaughter animal batch, } \\
3.96 \% \text { in herds }\end{array}$ & 13 EU countries \\
\hline \multirow{4}{*}{ Campylobacter spp. } & Broilers & $\begin{array}{l}\text { Caecum, } \mathrm{n}=17,445 \\
\text { flocks } / \text { batch }\end{array}$ & $22.18 \%$ & 18 EU countries \\
\hline & Turkey & Caecum, $\mathrm{n}=1228$ & $68.81 \%$ & 5 EU countries \\
\hline & Pigs & Feces, organs, n = 2504 & $2.12 \%$ & 9 EU countries \\
\hline & Cattle & $\begin{array}{l}\text { Animal samples, } \\
n=31,842\end{array}$ & $0.53 \%$ & 12 EU countries \\
\hline \multirow{2}{*}{ Yersinia enterocolitica } & Pigs & $\begin{array}{l}\text { Animal samples, } \\
\qquad \mathrm{n}=2354\end{array}$ & $0.43 \%$ & 7 EU countries \\
\hline & $\begin{array}{c}\text { Domestic livestock } \\
\text { other than pigs }\end{array}$ & $\begin{array}{c}\text { Animal samples, } \\
\mathrm{n}=12,834\end{array}$ & $1.66 \%$ & 6 EU countries \\
\hline \multirow{3}{*}{ Toxoplasma gondii } & Pigs & Blood, $\mathrm{n}=263$ & $22.05 \%$ & 4 EU countries \\
\hline & Sheep and goats & $\begin{array}{l}\text { Blood, animal samples, } \\
\qquad n=6818\end{array}$ & $5.47 \%$ & 14 EU countries \\
\hline & Cattle & $\begin{array}{l}\text { Blood, animal samples, } \\
\qquad \mathrm{n}=159\end{array}$ & $27.7 \%$ & 7 EU countries \\
\hline \multirow{3}{*}{ STEC } & Cattle & $\begin{array}{l}\text { Feces, animal samples, } \\
\qquad \mathrm{n}=390\end{array}$ & $3.59 \%$ & 2 EU countries \\
\hline & Pigs & $\begin{array}{l}\text { Feces, animal samples, } \\
\qquad \mathrm{n}=5\end{array}$ & $20 \%$ & 2 EU countries \\
\hline & Goats & $\begin{array}{l}\text { Feces, animal samples, } \\
\qquad \mathrm{n}=5\end{array}$ & $40 \%$ & 1 EU country \\
\hline
\end{tabular}

Table 3. Official data on prevalence of main biological hazards on carcasses at slaughter [21].

\begin{tabular}{|c|c|c|c|c|}
\hline Biological Hazard & Animal Species & Sampling & Prevalence & $\begin{array}{c}\text { Countries Reported } \\
\text { the Data }\end{array}$ \\
\hline \multirow{3}{*}{ Salmonella spp. } & $\begin{array}{l}\text { Broilers and turkey, } \\
\text { chilled carcasses }\end{array}$ & $\begin{array}{l}\text { Neck skin/carcass, } \\
n=2381\end{array}$ & $15.08 \%$ & 7 EU countries \\
\hline & $\begin{array}{c}\text { Cattle, sheep, goats and } \\
\text { horses - carcasses } \\
\text { before chilling }\end{array}$ & $\begin{array}{c}\text { Carcass swabs } 400 \mathrm{~cm}^{2} \\
\mathrm{n}=3848\end{array}$ & $0.55 \%$ & $8 \mathrm{EU}$ countries \\
\hline & Pigs & $\begin{array}{c}\text { Carcass swabs } \\
100 / 400 \mathrm{~cm}^{2} \\
\mathrm{n}=149,962\end{array}$ & $1.62 \%$ & 28 EU countries \\
\hline \multirow[t]{2}{*}{ Campylobacter spp. } & $\begin{array}{l}\text { Broilers, chilled } \\
\text { carcasses }\end{array}$ & $\begin{array}{c}\text { Neck skin/carcass, } \\
n=3746 \\
\text { (PHC Reg. 2073) }\end{array}$ & $\begin{array}{c}35 \%(8.94 \% \text { units with } \\
>1000 \mathrm{cfu})\end{array}$ & 10 EU countries \\
\hline & Fresh broiler meat & $1 / 10 / 25 \mathrm{~g}, \mathrm{n}=3621$ & $27.9 \%$ & 11 EU countries \\
\hline
\end{tabular}


Table 3. Cont.

\begin{tabular}{ccccc}
\hline Biological Hazard & Animal Species & Sampling & Prevalence & $\begin{array}{c}\text { Countries Reported } \\
\text { the Data }\end{array}$ \\
\hline Yersinia enterocolitica & Pigs & Carcass swabs, $\mathrm{n}=115$ & $0.87 \%$ & $1 \mathrm{EU}$ country \\
\hline & Broilers & $\begin{array}{c}\text { Carcass meat, } 25 \mathrm{~g}, \\
\mathrm{n}=31\end{array}$ & $22.58 \%$ & $1 \mathrm{EU}$ country \\
\cline { 2 - 5 } STEC & Goats & $\begin{array}{c}\text { Carcass swabs, } \\
\mathrm{n}=3\end{array}$ & $33.3 \%$ & $1 \mathrm{~cm} \mathrm{~cm}^{2}$, \\
\cline { 2 - 5 } & Horses, rabbits & $\begin{array}{c}\text { Carcass swabs, } 400 \mathrm{~cm}^{2}, \\
\mathrm{n}=9\end{array}$ & $0.0 \%$ & 1 EU country \\
\hline
\end{tabular}

\section{Underestimated Biological Hazards in Meat Chain Control}

\subsection{Yersinia enterocolitica}

Yersinia enterocolitica is an important and often neglected pathogenic microorganism in veterinary public health and meat hygiene [12]. Human yersiniosis is one of the leading foodborne zoonoses and has been declared as the fourth zoonosis after campylobacteriosis, salmonellosis, and Shiga toxin-producing E. coli infection, according to EU data [21]. Although bacterial transmission to humans usually occurs through raw or undercooked food or water, some infections have been reported under the low level of personal hygiene [12,15]. Infection with pathogenic $Y$. enterocolitica is usually manifested by milder gastrointestinal symptoms that usually do not require treatment. Therefore, the actual number of infected individuals is believed to be much higher than the number of reported cases, so that the public health importance of this bacterium has been underestimated over time [12].

\subsubsection{Farm Risk Factors and Serological Testing}

Domestic pigs are the most important carriers of pathogenic Y. enterocolitica strains as well as a source of contamination of meat intended for human consumption [12]. At the farm level, it is estimated that pathogen prevalence is higher in conventional intensive farming systems than in organic extensive farming systems [22] and may be seasonal [23]. Regarding the colonization and occurrence of $Y$. enterocolitica in different categories of pigs, most studies indicate persistence of the risk in fattening pigs. Fecal shedding of pathogens begins at one to three months of age and peaks at two to five months of age. After this age, fecal incidence decreases, but pigs remain seropositive for a longer period of time [24]. It is estimated that $35-70 \%$ of swine herds and $45-100 \%$ of individual finishing pigs are carriers of Y. enterocolitica [25]. Our recent study (unpublished) showed that despite the same (highest) biosecurity levels in integrated pig farms, the prevalence of pathogenic Y. enterocolitica was significantly different between farms, suggesting that risk factors for the occurrence of the pathogen in tonsils may be related to harvest level [26]. In contrast to integrated farming systems, a significant influence of biosecurity level on pathogen prevalence was found in small family farms, i.e., the lower the biosecurity level of the farm, the higher the pathogen prevalence [26].

In terms of risk factors, Virtanen et al. [27] found that infection (carrier status) and excretion of $Y$. enterocolitica in feces was prevented by the use of municipal water, purchase of pig feed from a single trusted supplier and organic production (i.e., protective factor). The risk factors for the excretion of $Y$. enterocolitica in feces are carrier status of the pathogen on tonsils, purchase of pig feed from multiple suppliers, feeding pigs before transport to slaughterhouse, and snout contact. Vilar et al. [28] also claim that the prevalence of Y. enterocolitica in pigs can be reduced by using only municipal water and an all-in/allout system, while a lack of bedding and the purchase of piglets from multiple farms are risk factors.

To categorize farms in terms of Yersinia risk, the use of serological monitoring prior to slaughter has been strongly recommended in recent years [29]. Felin et al. [30] re- 
ported strong correlation between seropositivity to Salmonella and Yersinia in fattening pigs. Moreover, the housing system was also important factor for Yersinia seroprevalence [30]. Serological results in FCI give the possibility for the slaughterhouse to risk-rank farms according to the risk of shedding Yersinia, and slaughter the pigs from high-risk farms at the end of the day and use hot water decontamination for these carcasses [15].

\subsubsection{Prevalence of Pathogen in Pigs}

Pigs are asymptomatic carriers of strains pathogenic to humans, mainly biotype 4 (serotype O:3) and less frequently biotype 2 (serotype O:9 and O:5.27). They are found in the oral cavity, particularly in the tonsils, submandibular lymph nodes, tongue, and intestines and feces [31]. It is common to find strains of bioserotype 4/O:3 on the surface of slaughtered carcasses due to fecal contamination, intestinal, and tonsil contents during slaughter processing [32]. The detection of Y. enterocolitica in the tonsils depends on numerous factors, such as the time of infection (on-farm, during transport, in the slaughterhouse barn) or slaughterhouse practices (cross-contamination). For example, the procedures during housing before slaughter are very important for the spread of pathogens between groups of pigs in lairage [29]. Nowak et al. [33] recorded a higher prevalence of $Y$. enterocolitica, particularly in the tonsils, in pigs slaughtered at the end of the day than in pigs slaughtered at the beginning. This suggests the contamination of pigs brought to slaughter from different sources, and contamination occurred via feces from previously dormant pigs in the herd. Indeed, after oral infection, the bacteria can be detected in the appendix and lymph nodes within only three hours $[29,33]$.

The prevalence of $Y$. enterocolitica in the tonsils of slaughtered pigs varies widely in Europe, ranging from 1.8 to $93 \%[34,35]$. The highest recovery rate of the pathogen is found in tonsils, and it is lower in intestines or on pig carcasses. In the UK, the prevalence of Y. enterocolitica in tonsils was $28.7 \%$, while in carcasses, it was only $1.8 \%$ [36]. In Belgian slaughterhouses, $55.1 \%$ of tonsil samples, $25.1 \%$ of fecal samples, and $39.1 \%$ of carcasses were positive. The incidence of the pathogens was highest in the tonsil region $(29 \%)$ and much lower in the pelvic and sternum regions (7-16\%) [37]. Centorame et al. [38] reported a relatively low prevalence of $9.31 \%$ in the tonsils, but the dominance of bioserotype 4/O:3 $(95.74 \%)$ indicates the importance of pigs as natural reservoirs for human yersiniosis. In Brazil, a prevalence of $25.2 \%$ was reported from pig tonsils with only two pathogenic strains, confirming high variability in pathogen persistence between countries [39]. In a Croatian study [32], Y. enterocolitica bioserotype 4/O:3 strains were recovered from 33.3\% of tonsils and $10.25 \%$ of mandibular lymph nodes. A recent study from the same pig farming system and slaughterhouses in Croatia revealed a prevalence of $43 \%$ of pathogenic Y. enterocolitica 4/O:3 in pig tonsils [26]. The above survey reports indicate high variability in prevalence between studies, which is possibly due to differences in farm management, sampling methods, hygienic practices at slaughter, and, in particular, methods of pathogen isolation and detection.

\subsubsection{Meat Contamination at Slaughter and Meat Processing}

Regarding the risk of meat contamination during slaughter, Vilar et al. [28] claim that the presence of $Y$. enterocolitica in the intestines, tonsils, and offal are the main risk factors, which also leads to a higher probability of cross-contamination. The prevention of meat contamination during slaughter should be based on standard operative procedures such as bunging/rectum tying and removal of the head together with the tonsils [40]. Removal of the tonsils is a critical step as, for example, the parts of the tonsils remaining in the throat after evisceration can be a major cause of the spread of pathogens from lymphatic to muscle tissue $[32,41,42]$. It is also suggested to partially remove the viscera by leaving the tongue and tonsils on the halves and omitting the incision of the mandibular lymph nodes. In countries such as Denmark and Canada, carcass halves are decontaminated with hot water or steam to reduce the incidence of Y. enterocolitica [43]. 
With regard to slaughter techniques and possible failures in processing hygiene, contamination with pathogens is expected to occur mainly in the meat of the neck, head, tongue and throat region, less so in the carcass [44,45]. Martins et al. [46] isolated Y. enterocolitica from the tonsils and lymph nodes of pigs but not from the environmental samples or from the meat after carcass splitting. However, the presence of pathogenic $Y$. enterocolitica, even in low numbers, is a risk factor for consumers because of its ability to grow at lower temperatures, as well as temperature abuse during chilling $[47,48]$. In this regard, minced meat, characterized by high microbiological risk, is a possible source of Y. enterocolitica [49]. Visnubhatla et al. [50] recorded a high level of contamination of minced beef and pork with the pathogen Y. enterocolitica up to $6 \log \mathrm{CFU} / \mathrm{g}$, which poses a risk to the consumer. Recently, Ferl et al. [51] reported Y. enterocolitica contamination in minced pork (22.6\%, $\mathrm{N}=62$ ) and seasoned minced meat $(11.5 \%)$. Similarly, studies from Argentina, India, or Malesia indicate a higher prevalence of pathogenic $Y$. enterocolitica in fresh pork products on the market, but these results are highly variable and depend on risk factors such as the hygiene level of slaughter or farming practices [52-54].

\subsection{Toxoplasma gondii}

Toxoplasmosis is a worldwide zoonosis and one of the most common meat-borne parasitic diseases [12,16]. Recently, Aguirre et al. [55] presented the One Health approach to toxoplasmosis, which is one of the leading causes of death in the USA and has a high seroprevalence in humans (up to $90 \%$ in countries with low sanitary measures) [55]. Humans can become infected with the parasite via ingestion of oocysts directly from soil or in contaminated food or water; via ingestion of tissue cysts in uncooked/raw infected meat; or vertically from mother to child during primary infection in pregnancy [56]. However, it is known that consumption of undercooked meat is the most important factor [57]. In Europe, pork is generally considered the main source of invasions, while studies in Norway and France have shown that lamb is a more significant risk factor [58]. However, there is no official requirement for surveillance or control of T. gondii in meat-producing animals. Given the high prevalence and public health importance of T. gondii, it is necessary to establish an effective system to control this zoonosis in the meat production chain $[12,16]$. In the first place, the prevention of toxoplasmosis should be based on comprehensive control at the level of primary production (farm) and at the slaughterhouse, together with deactivation processes in meat processing [13]. To improve food safety, the European Food Safety Authority (EFSA) recommends the review of biosecurity measures in conventional finishing farms and serology in different types of herds to identify high-risk farms and use them within food chain information system [10,58].

\subsubsection{Serological Testing-Pre-Harvest Control}

The global seroprevalence of toxoplasmosis in pigs is estimated to $19 \%$, and it is higher in free ranged systems [16]. Contrary, seroprevalence is lowest in intensive pig farming [59]. Serological methods are considered the primary method for diagnosing toxoplasmosis because it is asymptomatic in pigs and the cysts are too small to be detected during meat inspection at the slaughterhouse. To date, serological tests are regularly used to detect exposure in pigs and seroprevalence in general, both in pigs and other animals and in humans [12]. Serological testing for porcine toxoplasmosis in a slaughterhouse has proven to be the most practical method to obtain risk data from the farm and to take further control measures accordingly [15]. In particular, EFSA recommends serological testing of fattening pigs kept in uncontrolled housing systems [43].

Serology can only be used to assess the risk of infection to humans if there is a correlation between seroprevalence and the presence of cysts in meat. Opsteegh et al. [60] investigated this correlation for major domestic animal species and estimated that the probability of detection of parasites in seropositive animals was highest in pigs (58.8\%), followed by chickens (53.4\%), sheep, and goats (39.4\% and $35.0 \%)$, and it was the lowest in horses and cattle. These data suggest that the correlation between antibody detection 
against T. gondii and direct parasite detection is high in pigs, small ruminants, and chickens. In these species, the use of serology can help determine the risk to the consumer, but it may not be as useful in other species, such as horses and cattle. In addition, a seronegative result does not necessarily mean that the meat is free of T. gondii. Therefore, an integrated approach combining serology with molecular techniques would provide a multilevel understanding of the epidemiology of the parasite, as molecular detection provides additional information on the risk of meat consumption [61]. In studies by Jurankova et al. [62], the brain, heart, and lungs were the preferred sites for T. gondii cysts in experimentally infected pigs.

Different serological methods were used to detect IgG antibodies in pig serum and meat juice. Meat juice is commonly used because it is readily available at slaughter and can also be used to detect other zoonotic diseases such as salmonellosis, yersiniosis, and trichinosis [43]. It should be noted that IgG antibody levels are lower in meat juice compared to serum, so it is necessary to use a lower dilution factor for meat juice samples. Antibodies usually persist until the time of slaughter [63], but the immune response cannot be measured immediately after infection. Sometimes, an animal's immune system is unable to produce a measurable immune response despite carrying a pathogen. Therefore, serological methods are not always suitable for testing individual carcasses as part of a food safety assessment $[16,29,30]$. However, Felin et al. [15] investigated the seroprevalence of fattening pigs for T. gondii to assess the feasibility of serological surveillance in the slaughterhouse and the usability of the results as part of the FCI. Although the seroprevalence of T. gondii was generally low, some farms were found with $100 \%$ seroprevalence. Serological surveillance in this case would allow the identification of farms where existing biosecurity measures should be introduced and improved. These farms should be visited and advised by veterinarians to improve biosecurity measures, reduce risk, and increase the safety of meat for consumers. Carcasses of pigs from such high-risk holdings should be frozen or subjected to heat treatment [12].

\subsubsection{Controls at the Slaughterhouse and during Meat Processing}

Toxoplasma gondii is considered a priority risk in meat inspection of pigs, farmed game (wild boar, deer), sheep, and goats [12]. It is impossible to detect the risk of T. gondii through the traditional way of inspection in slaughterhouses [10]; therefore, additional (pre-)testing in the meat chain is needed. Based on the collected data on the hazards in the production chain (e.g., serological testing of animals), the necessary measures are selected to reduce or eliminate the risks in the meat production chain, such as heat treatment and freezing of meat [64].

Several processing methods can be used to decontaminate meat containing bradyzoites of T. gondii [65]. Heat treatment is the safest method to inactivate the parasite [66]. It is recommended to cook pork at a temperature of $70^{\circ} \mathrm{C}$, and the meat should be cooked thoroughly until the internal temperature reaches $66^{\circ} \mathrm{C}$. Cooking temperature and avoidance of cross-contamination are considered the most important factors in preventing T. gondii infection from meat consumption [63]. Both cooking temperature and bradysoite concentration of T. gondii in muscle are the highest risk factors for transmission to humans [67]. Most cysts are inactivated by temperatures below $-12{ }^{\circ} \mathrm{C} / 2$ days [13]. Gamma radiation has the same effect as high pressure treatment at $300 \mathrm{MPa}$ or more [68]. The problem may be the effect of these methods on the color, texture, and flavor of the meat and therefore may be unattractive to the consumer. In addition, the use of gamma radiation and high-pressure processing may be restricted by legislation and may incur high costs [69]. As for cured meat products, most studies suggest that cysts of T. gondii are destroyed during salt curing, but the inactivation of these cysts depends on the maturation time, temperature of storage, and salt concentration in the curing process [70-73]. 


\section{Food Chain Information and Epidemiological Indicators}

A central role in the meat safety system is played by food chain information, which should provide relevant guidance for the management of a group of animals or a herd in relation to the prioritized biological hazards [12]. The usual information on health, drug treatment, nutrition, operational measures, etc. in the above context of the meat inspection system is not sufficient as it does not cover all the hazards and control measures discussed before, e.g., for T. gondii or Y. enterocolitica [15]. When carrying out inspection procedures, the official veterinarian shall take into account the certificates and attestations accompanying the animals and any declarations made by the veterinarian, including official and authorized veterinarians who have carried out controls at the level of primary production $[2,3,15]$. This information should help to increase food safety for consumers, as it would act as a link between the farm and the slaughterhouse [10].

However, in most European countries, there are currently no regular monitoring programs for the main meat-borne zoonoses on farms, except for salmonellosis in chicken broilers, turkey broilers, commercial chicken flocks, turkey and chicken breeding flocks and strains of $S$. Enteritidis, $S$. Typhimurium, S. Hadar, S. Infantis, and S. Virchow, in breeding flocks of chickens [21]. If these data from primary production are credible, complete, and applicable, they can greatly reduce the risk and hazards, i.e., increase the level of food safety [15]. Therefore, the categorization of risks in certain stages of production from farm to slaughterhouse should be enabled by Harmonized Epidemiological Indicators (HEIs) [12-14]. Thus, the risk of herds/flocks on the farm in terms of microbiological hazards can be assessed by monitoring the audit of the animal procurement system, monitoring husbandry practices and the presence/absence of target bacteria in the feces of the animals [12].

Monitoring of transport of slaughter animals and housing conditions at the slaughterhouse prior to slaughter provides information on the risk of a particular group of animals (batch). During slaughter processing, the risk is assessed by the bacteriological status of the carcass before and after skinning and before chilling. By microbiological testing after carcass chilling, we obtain data on the performance of the system in relation to the set targets (microbiological criteria for specific bacteria) on the carcass [9-13]. Accordingly, low-risk animals in relation to e.g., Yersinia are handled on a standard slaughter line that has a proven ability to ensure the achievement of carcass targets (e.g., absence of Yersinia) through good hygiene and production practices and the HACCP system. On the other hand, carcasses of animals from high-risk farms (e.g., seropositive to Yersinia) should be subjected to a decontamination process (steam, hot water) at the end of the slaughter line to reduce the potential risk. Where the risk of Toxoplasma is high, measures should include thermal treatment of the meat [9-13].

\section{Conclusions}

Nowadays, meat hygiene is confronted with new threats, making the veterinary profession even more important in the context of an integrated system for ensuring meat safety and a risk-based approach to official controls. In order to identify health risks, a comprehensive approach to meat production and inspection must incorporate knowledge of primary meat production and hygiene and all available information from the entire production system. In a safety assessment of meat, it is important to analyze data on the food chain (FCI), epidemiological indicators, herd health, animal welfare, and hygiene practices in slaughterhouses/farms. In this context, the importance of veterinarians at farm level is obvious, as is the flow of food chain information from farm to slaughterhouse and vice versa. Meat inspection is a logical extension with preventive measures and controls in primary production. However, even perfect management and prevention in primary production cannot guarantee reduced risk if hygiene and processing practices in slaughterhouses are poor. For both Y. enterocolitica and T. gondii, the control strategy should be based on epidemiological indicators and consequent intervention protocols to ensure safe meat for human consumption. 
Author Contributions: Conceptualization, N.Z.; writing - original draft preparation, M.K.; writingreview and editing, N.Z. All authors have read and agreed to the published version of the manuscript.

Funding: This research received no external funding.

Institutional Review Board Statement: Not applicable.

Informed Consent Statement: Not applicable.

Data Availability Statement: Data is contained within the article.

Conflicts of Interest: The authors declare no conflict of interest.

\section{References}

1. Sofos, J.N. Challenges to meat safety in the 21st century. Meat. Sci. 2008, 78, 3-13. [CrossRef] [PubMed]

2. Edwards, D.S.; Johnston, M.; Mead, G.C. Meat Inspection: An Overview of Present Practices and Future Trends. Vet. J. 1997, 154, 135-147. [CrossRef]

3. Ries, L.E.; Hoelzer, K. Implementation of Visual-Only Swine Inspection in the European Union: Challenges, Opportunities, and Lessons Learned. J. Food Protect. 2020, 83, 1918-1928. [CrossRef]

4. Zdolec, N.; Vujević, I.; Dobranić, V.; Juras, M.; Grgurević, N.; Ardalić, D.; Njari, B. Prevalence of Cysticercus bovis in slaughtered cattle determined by traditional meat inspection in Croatian abattoir from 2005 to 2010. Helminthologia 2012, 49, $229-232$. [CrossRef]

5. Ng-Nguyen, D.; Stevenson, M.A.; Traub, R.J. A systematic review of taeniasis, cysticercosis and trichinellosis in Vietnam. Parasit. Vectors 2017, 10, 1-15. [CrossRef] [PubMed]

6. Trevisan, C.; Sotiraki, S.; Laranjo-Gonzáles, M.; Dermauw, V.; Wang, Z.; Kärssin, A.; Cvetkovikj, A.; Winkler, A.S.; Abraham, A.; Bobić, B.; et al. Epidemiology of taeniosis/cysticercosis in Europe, a systematic review: Eastern Europe. Parasit. Vectors 2018, 11, 1-11, . [CrossRef]

7. $\quad$ Eichenberger, R.M.; Thomas, L.F.; Gabriël, S.; Bobić, B.; Devleesschauwer, B.; Robertson, L.J.; Saratsis, A.; Torgerson, P.R.; Braae, U.C.; Dermauw, V.; et al. Epidemiology of Taenia saginata taeniosis/cysticercosis: A systematic review of the distribution in East, Southeast and South Asia. Parasit. Vectors 2020, 13, 1-11. [CrossRef]

8. Alban, L.; Petersen, J.V.; Bækbo, A.K.; Østergaard Pedersen, T.; Kruse, A.B.; Pacheco, G.; Halberg Larsen, M. Modernising meat inspection of pigs-A review of the Danish process from 2006-2020. Food Control 2021, 119, 1-11. [CrossRef]

9. Blagojević, B.; Nesbakken, T.; Alvseike, O.; Vågsholm, I.; Antic, D.; Johlerf, S.; Houf, K.; Meemken, D.; Nastasijevic, I.; Vieira Pinto, M.; et al. Drivers, opportunities, and challenges of the European risk-based meat safety assurance system. Food Control 2021, 124, 1-12. [CrossRef]

10. Nastasijević, I.; Vesković, S.; Milijašević, M. Meat safety: Risk based assurance systems and novel technologies. Meat Technol. 2020, 61, 97. [CrossRef]

11. Blagojević, B.; Antić, D. Assessment of potential contribution of official meat inspection and abattoir process hygiene to biological safety assurance of final beef and pork carcasses. Food Control 2014, 36, 174-182. [CrossRef]

12. Ninios, T.; Lundén, J.; Korkeala, H.; Fredriksson-Ahomaa, M. Meat Inspection and Control in the Slaughterhouse; John Wiley \& Sons: Oxford, UK, 2014.

13. Bunčić, S.; Alban, L.; Blagojević, B. From traditional meat inspection to development of meat safety assurance programs in pig abattoirs-The European situation. Food Control 2019, 106, 1-12. [CrossRef]

14. Gomes-Neves, E.; Muller, A.; Correia, A.; Capas-Peneda, S.; Carvalho, M.; Vieira, S.; Fonseca Cardoso, M. Food Chain Information: Data Quality and Usefulness in Meat Inspection in Portugal. J. Food Protect. 2018, 81, 1890-1896, . [CrossRef] [PubMed]

15. Felin, E. Towards Risk-Based Meat Inspection: Prerequisites of Risk-Based Meat Inspection of Pigs in Finland. Ph.D. Thesis, University of Helsinki, Helsinki, Finland, June 2019.

16. Foroutan, M.; Fakhric, Y.; Riahid, S.M.; Ebrahimpoure, S.; Namroodif, S.; Taghipourb, A.; Spoting, A.; Gamblei, H.R.; Rostami, A. The global seroprevalence of Toxoplasma gondii in pigs: A systematic review and meta-analysis. Vet. Parasitol. 2019, $269,42-52$. [CrossRef] [PubMed]

17. Olsen, A.; Berg, R.; Tagel, M.; Must, K.; Deksne, G.; Larsen Enemark, H.; Alban, L.; Vang Johansen, M.; Vedel Nielsen, H.; Sandberg, M.; et al. Seroprevalence of Toxoplasma gondii in domestic pigs, sheep, cattle, wild boars, and moose in the Nordic-Baltic region: A systematic review and meta-analysis. Parasite Epidemiol. Control 2019, 3, 1-13, . [CrossRef]

18. Golden, C.E.; Mishra, A. Prevalence of Salmonella and Campylobacter spp. in Alternative and Conventionally Produced Chicken in the United States: A Systematic Review and Meta-Analysis. J. Food Protect. 2020, 83, 1181-1197, . [CrossRef]

19. Thomas, K.M.; de Glanville, W.A.; Barker, G.C.; Benschop, J.; Buza, J.J.; Cleaveland, S.; Davis, M.A.; French, N.P.; Mmbaga, B.T.; Prinsen, G.; et al. Prevalence of Campylobacter and Salmonella in African food animals and meat: A systematic review and meta-analysis. Int. J. Food Microbiol. 2020, 315, 1-22, . [CrossRef]

20. Gutema, F.D.; Agga, G.E.; Abdi, R.D.; De Zutter, L.; Duchateau, L.; Gabriël, S. Prevalence and Serotype Diversity of Salmonella in Apparently Healthy Cattle: Systematic Review and Meta-Analysis of Published Studies, 2000-2017. Front. Vet. Sci. 2019, 6, 1-11. [CrossRef] 
21. EFSA. The European union one health 2018 zoonoses report. EFSA J. 2019, 17, 1-275, . [CrossRef]

22. Laukkanen, R.; Martínez, P.O.; Siekkinen, K.M.; Ranta, J.; Maijala, R.; Korkeala, H. Contamination of Carcasses with Human Pathogenic Yersinia enterocolitica 4/O:3 Originates from Pigs Infected on Farms. Foodborne Pathog. Dis. 2009, 6, 681-688, . [CrossRef]

23. Fondrevez, M.; Minvielle, B.; Labbé, A.; Houdayer, C.; Rose, N.; Esnault, E.; Denis, M. Prevalence of pathogenic Yersinia enterocolitica in slaughter-aged pigs during a one-year survey, 2010-2011, France. Int. J. Food Microbiol. 2014, 174, 56-62, . [CrossRef] [PubMed]

24. Koskinen, J.; Keto-Timonen, R.; Virtanen, S.; Vilar, M.J.; Korkeala, H. Prevalence and Dynamics of Pathogenic Yersinia enterocolitica 4/O:3 Among Finnish Piglets, Fattening Pigs and Sows. Foodborne Pathog. Dis. 2019, 16, 831-839, . [CrossRef]

25. Shoaib, M.; Shehzad, A.; Raza, H.; Niazi, S.; Khan, I.M.; Akhtar, W.; Safdar, W.; Wang, Z. A comprehensive review on the prevalence, pathogenesis and detection of Yersinia enterocolitica. RSC Adv. 2019, 9, 41010-41021. [CrossRef]

26. Pažin, V. Phenotypic and genetic characteristics of Yersinia enterocolitica isolated from pork production chain. Unpublished.

27. Virtanen, S.E.; Salonen, L.K.; Laukkanen, R.; Hakkinen, M.; Korkeala, H. Factors related to the prevalence of pathogenic Yersinia enterocolitica on pig farms. Epidemiol. Infect. 2011, 139, 1919-1927, . [CrossRef]

28. Vilar, M.J.; Virtanen, S.; Laukkanen-Ninios, R.; Korkeala, H. Bayesian modelling to identify the risk factors for Yersinia enterocolitica contamination of pork carcasses and pluck sets in slaughterhouses. Int. J. Food Microbiol. 2015, 197, 53-57, . [CrossRef] [PubMed]

29. Bonardi, S.; Bruini, I.; D'incau, M.; Van Damme, I.; Carniel, E.; Brémont, S.; Cavallini, P.; Tagliabue, S.; Brindani, F. Detection, seroprevalence and antimicrobial resistance of Yersinia enterocolitica and Yersinia pseudotuberculosis in pig tonsils in Northern Italy. Int. J. Food Microbiol. 2016, 235, 125-132, . [CrossRef]

30. Felin, E.; Jukola, E.; Raulo, S.; Fredriksson-Ahomaa, M. Meat Juice Serology and Improved Food Chain Information as Control Tools for Pork-Related Public Health Hazards. Zoonoses Public Health 2014, 62, 456-464. [CrossRef] [PubMed]

31. Moreira, L.M.; Milan, C.; Gonçalves, T.G.; Nunes Ebersol, C.; Gonzales de Lima, H.; Timm, C.D. Contamination of pigs by Yersinia enterocolitica in the abattoir flowchart and its relation to the farm. Ciênc. Rural 2019, 49, 1-7. [CrossRef]

32. Zdolec, N.; Dobranić, V.; Filipović, I. Prevalence of Salmonella spp. and Yersinia enterocolitica in/on tonsils and mandibular lymph nodes of slaughtered pigs. Folia Microbiol. 2015, 60, 131-135. [CrossRef] [PubMed]

33. Nowak, B.; Mueffling, T.V.; Caspari, K.; Hartung, J. Validation of a method for the detection of virulent Yersinia enterocolitica and their distribution in slaughter pigs from conventional and alternative housing systems. Vet. Microbiol. 2006, 117, 219-228, . [CrossRef] [PubMed]

34. O'Sullivan, T.; Friendship, R.; Blackwell, T.; Pearl, D.; McEwen, B.; Carman, S.; Slavić, Đ.; Dewey, C. Microbiological identification and analysis of swine tonsils collected from carcasses at slaughter. Can. J. Vet. Res. 2011, 75, 106-111.

35. Martínez, P.O.; Fredriksson-Ahomaa, M.; Pallotti, A.; Rosmini, R.; Houf, K.; Korkeala, H. Variation in the Prevalence of Enteropathogenic Yersinia in Slaughter Pigs from Belgium, Italy, and Spain. Foodborne Pathog. Dis. 2011, 8, 445-450. [CrossRef]

36. Powell, L.F.; Cheney, T.E.A.; Williamson, S.; Guy, E.; Smith, R.P.; Davies, R.H. A prevalence study of Salmonella spp., Yersinia spp., Toxoplasma gondii and porcine reproductive and respiratory syndrome virus in UK pigs at slaughter. Epidemiol. Infect. 2015, 144, 1538-1549. [CrossRef]

37. Van Damme, I.; Berkvens, D.; Vanantwerpen, G.; Baré, J.; Houf, K.; Wauters, G.; De Zutter, L. Contamination of freshly slaughtered pig carcasseswith enteropathogenic Yersinia spp.: Distribution, quantification and identification of risk factors. Int. J. Food Microbiol. 2015, 204, 33-40. [CrossRef] [PubMed]

38. Centorame, P.; Sulli, N.; De Fanis, C.; Colangelo, O.V.; De Massis, F.; Conte, A.; Persiani, T.; Marfoglia, C.; Scattolini, S.; Pomilio, F.; et al. Identification and characterization of Yersinia enterocolitica strains isolated from pig tonsils at slaughterhouse in Central Italy. Vet. Ital. 2017, 53, 331-344. [CrossRef] [PubMed]

39. Wildemann, P.; Gava, D.; Pilegi Sfaciotte, R.A.; Melo, F.D.; Ferraz, S.M.; da Costa, U.M.; Vaz, E.K. Low occurrence of pathogenic Yersinia enterocolitica in pig tonsils at slaughter in Southern Brazil. Trop. Anim. Health Prod. 2017, 50, 671-675. [CrossRef] [PubMed]

40. Laukkanen, R.; Ranta, J.; Dong, X.; Hakkinen, M.; Martínez, P.O.; Lundén, J.; Johansson, T.; Korkeala, H. Reduction of Enteropathogenic Yersinia in the Pig Slaughterhouse by Using Bagging of the Rectum. J. Food Protect. 2010, 73, $2161-2168$. [CrossRef]

41. Nesbakken, T.; Eckner, K.; Høidal, H.K.; Røtterud, O.J. Occurrence of Yersinia enterocolitica and Campylobacter spp. in slaughter pigs and consequences for meat inspection, slaughtering and dressing procedures. Int. J. Food Microbiol. 2003, 80, $231-240$. [CrossRef]

42. Bonardi, S.; Alpigiani, I.; Pongolini, S.; Morganti, M.; Tagliabue, S.; Bacci, C.; Briandini, F. Detection, enumeration and characterization of Yersinia enterocolitica 4/O:3 in pig tonsils at slaughter in Northern Italy. Int. J. Food Microbiol. 2014, $177,9-15$. [CrossRef]

43. Fredriksson-Ahomaa. Yersinia enterocolitica. In Foodborne Diseases, 3rd ed.; Dodd, C.E.R., Aldsworth, T., Stein, R.A., Cliver, D.O., Riemann, H.P., Eds.; Academic Press: London, UK, 2017; pp. 223-232.

44. Messelhäusser, U.; Kämpf, P.; Colditz, J.; Bauer, H.; Schreiner, H.; Höller, C.; Busch, U. Qualitative and Quantitative Detection of Human Pathogenic Yersinia enterocolitica in Different Food Matrices at Retail Level in Bavaria. Foodborne Pathog. Dis. 2011, 8, 39-44. [CrossRef] 
45. Laukkanen-Ninios, R.; Fredriksson-Ahomaa, M.; Maijala, R.; Korkeala, H. High prevalence of pathogenic Yersinia enterocolitica in pig cheeks. Food Microbiol. 2014, 43, 50-52. [CrossRef]

46. Martins, B.T.F.; Botelho, C.V.; Lopes Silva, D.A.; Lanna, F.G.P.A.; Libero Grossi, J.; Campos-Galvão, M.E.M.; Seiti Yamatogi, R.; Pfrimer Falcăo, J.; dos Santos Bersot, L.; Nero, L.A. Yersinia enterocolitica in a Brazilian pork production chain: Tracking of contamination routes, virulence and antimicrobial resistance. Int. J. Food Microbiol. 2018, 276, 5-9. [CrossRef]

47. Bijelić, T.; Dobranić, V.; Kazazić, S.; Filipović, I.; Dumbović, Z.; Zdolec, N. Growth of Yersinia enterocolitica O:3 in minced pork meat. Vet. Stn. 2017, 48, 25-29.

48. Vujić, K.; Kiš, M.; Zdolec, N. Microbial contamination of food refrigerators in households. Veterinar 2020, $58,23-27$.

49. Fredriksson-Ahomaa, M.; Korkeala, H. Molecular epidemiology of Yersinia enterocolitica 4/O:3. In The Genus Yersinia; Skurnik, M., Bengoechea, J.A., Granfors, K., Eds.; Springer: New York, NY, USA, 2003; pp. 295-302.

50. Vishnubhatla, A.; Oberst, R.D.; Fung, D.Y.C.; Wonglumsom, W.; Hays, M.P.; Nagaraja, T.G. Evaluation of a 5'-nuclease (TaqMan) Assay for the Detection of Virulent Strains of Yersinia enterocolitica in Raw Meat and Tofu Samples. J. Food Protect. 2001, 64, 355-360, . [CrossRef]

51. Ferl, M.; Mäde, D.; Braun, P.G. Combined molecular biological and microbiological detection of pathogenic Yersinia enterocolitica in spiced ground pork, meat for production of ground pork and raw sausages. JVL 2020, 15, 27-35. [CrossRef]

52. Lucero-Estrada, C.S.M.; Soria, J.M.; Favier, G.I.; Escudero, M.E. Evaluation of the pathogenic potential, antimicrobial susceptibility and genomic relations of Yersinia enterocolitica strains from food and human origin. Can. J. Microbiol. 2015, 61, 851-860, . [CrossRef]

53. Latha, C.; Anu, C.J.; Ajaykumar, V.J.; Sunil, B. Prevalence of Listeria monocytogenes, Yersinia enterocolitica, Staphylococcus aureus, and Salmonella enterica Typhimurium in meat and meat products using multiplex polymerase chain reaction. Vet. World 2017, 10, 927-931. [CrossRef] [PubMed]

54. Thong, K.L.; Tan, L.K.; Ooi, P.T. Genetic diversity, virulotyping and antimicrobial resistance susceptibility of Yersinia enterocolitica isolated from pigs and porcine products in Malaysia. J. Sci. Food Agric. 2017, 98, 87-95. [CrossRef]

55. Aguirre, A.A.; Longcore, T.; Barbieri, M.; Dabritz, H.; Hill, D.; Klein, P.N.; Lepczyk, C.; Lilly, E.L.; McLeod, R.; Milcarsky, J.; et al. The One Health Approach to Toxoplasmosis: Epidemiology, Control, and Prevention Strategies. Ecohealth 2019, 16, 378-390. [CrossRef] [PubMed]

56. Plaza, J.; Dámek, F.; Villena, I.; Innes, E.A.; Katzer, F.; Hamilton, C.M. Detection of Toxoplasma gondii in retail meat samples in Scotland. Food Waterborne Parasitol. 2020, 20, 1-6. [CrossRef] [PubMed]

57. Belluco, S.; Simonato, G.; Mancin, M.; Pietrobelli, M.; Rici, A. Toxoplasma gondii infection and food consumption: A systematic review and meta-analysis of case-controlled studies. Crit. Rev. Food Sci. Nutr. 2018, 58, 3085-3096, . [CrossRef]

58. EFSA. Scientific opinion of the panel on biological hazards on a request from EFSA on surveillance and monitoring of Toxoplasma in humans, foods and animals. EFSA J. 2007, 583, 1-64, . [CrossRef]

59. Van der Giessen, J.; Fonville, M.; Bouwknegt, M.; Langelaar, M.; Vollema, A. Seroprevalence of Trichinella spiralis and Toxoplasma gondii in pigs from different housing systems in The Netherlands. Vet. Parasitol. 2007, 148, 371-374. [CrossRef]

60. Opsteegh, M.; Maas, M.; Schares, G.; van der Giessen, J. Relationship between seroprevalence in the main livestock species and presence of Toxoplasma gondii in meat (GP/EFSA/BIOHAZ/2013/01) An extensive literature review, Final report. EFSA Support. Publ. 2016, 13, 1-294. [CrossRef]

61. Gazzonis, A.L.; Marangi, M.; Villa, L.; Ragona, M.E.; Olivieri, E.; Zanzani, S.A.; Giangaspero, A.; Manfredi, M.T. Toxoplasma gondii infection and biosecurity levels in fattening pigs and sows: Serological and molecular epidemiology in the intensive pig industry (Lombardy, Northern Italy). Parasitol. Res. 2018, 117, 539-546, . [CrossRef]

62. Juránková, J.; Basso, W.; Neumayerová, H.; Baláž, V.; Jánová, E.; Sidler, X.; Deplazes, P.; Koudela, B. Brain is the predilection site of Toxoplasma gondii in experimentally inoculated pigs as revealed by magnetic capture and real-time PCR. Food Microbiol. 2014, 38, 167-170, . [CrossRef] [PubMed]

63. Basso, W.; Grimm, F.; Ruetten, M.; Djokić, V.; Blaga, R.; Sidler, X.; Deplazes, P. Experimental Toxoplasma gondii infections in pigs: Humoral immune response, estimation of specific IgG avidity and the challenges of reproducing vertical transmission in sows. Vet. Parasitol. 2017, 236, 76-85, . [CrossRef]

64. Knezić, A.; Zdolec, N. Risk-based meat inspection-The example of the pork chain. Hrvat. Vet. Vjesn. 2020, 28, 2, 26-32.

65. Franssen, F.; Gerard, C.; Cozma, A.; Vieira-Pinto, M.; Režek Jambrak, A.; Rowan, N.J.; Paulsen, P.; Rozycki, M.; Tysnes, K.; Rodriguez-Lazaro, D.; et al. Inactivation of parasite transmission stages: Efficacy of treatments on food of animal origin. Trends Food Sci. Technol. 2019, 83, 114-128. [CrossRef]

66. Kijlstra, A.; Jongert, E. Control of the risk of human toxoplasmosis transmitted by meat. Int. J. Parasitol. 2008, 38, 1359-1370, . [CrossRef]

67. McCurdy, S.M.; Takeuchi, M.T.; Edwards, Z.M.; Edlefsen, M.; Kang, D.H.; Mayes, V.E.; Hillers, V.N. Food safety education initiative to increase consumer use of food thermometers in the United States. Br. Food J. 2006, 108, 775-794. [CrossRef]

68. Condoleo, R.; Rinaldi, L.; Sette, S.; Mezher, Z. Risk assessment of human toxoplasmosis associated with the consumption of Pork Meat in Italy. Risk Anal. 2018, 38, 1202-1222, . [CrossRef] [PubMed]

69. Lindsay, D.S.; Collins, M.V.; Holliman, D.; Flick, G.J.; Dubey, J.P. Effects of high-pressure processing on Toxoplasma gondii tissue cysts in ground pork. J. Parasitol. 2006, 92, 195-196. [CrossRef]

70. Opsteegh, M.; Kortbeek, T.M.; Havelaar, A.H.; van Giessen, J.W. Intervention strategies to reduce human Toxoplasma gondii disease Burden. Clin. Infect. Dis. 2015, 60, 101-107. [CrossRef] [PubMed] 
71. Pott, S.; Koethe, M.; Bangoura, B.; Zöller, B.; Daugschies, A.; Straubinger, R.K.; Fehlhaber, K.; Ludewig, M. Effects of pH, sodium chloride, and curing salt on the infectivity of Toxoplasma gondii tissue cysts. J. Food Protect. 2013, 76, 1056-1061. [CrossRef]

72. Herrero, L.; Jesús Gracia, M.; Pérez-Arquillué, C.; Lázaro, R.; Herrera, A.; Bayarri, S. Toxoplasma gondii in raw and dry-cured ham: The influence of the curing process. Food Microbiol. 2017, 65, 213-220. [CrossRef] [PubMed]

73. Hill, D.E.; Luchansky, J.; Porto-Fett, A.; Gamble, H.R.; Fournet, V.M.; Hawkins-Cooper, D.S.; Urban, J.F.; Gajadhar, A.A.; Holley, R.; Juneja, V.K.; et al. Rapid inactivation of Toxoplasma gondii bradyzoites during formulation of dry cured ready-to-eat pork sausage. Food Waterborne Parasitol. 2018, 12, 1-7. [CrossRef] 